\title{
The first occurrence of Cobitis paludica (de Buen, 1930) in the Segura River Basin (SE Iberian Peninsula)
}

\author{
D. Verdiell-Cubedo*, F.J. Oliva-Paterna, A. Ruiz-Navarro and M. Torralva
}

Departamento de Zoología y Antropología Física. Facultad de Biología. Universidad de Murcia. 30100 Murcia.

* Corresponding author: verdiell@um.es

Received: $18 / 11 / 11 \quad$ Accepted: 30/1/12

\begin{abstract}
The first occurrence of Cobitis paludica (de Buen, 1930) in the Segura River Basin (SE Iberian Peninsula)

The aim of the present report is to describe the establishment of viable populations of Cobitis paludica (de Buen, 1930) in the Segura River Basin. We found two isolated populations: one located in the upper part of the Segura River and the mouth of its tributary, the Zumeta River, and another in the Mundo River, between the Talave and Camarillas reservoirs. We hypothesised that the introduction of this species may be attributable to the deliberate or accidental introduction by anglers or fish translocation from the Tajo-Segura interbasin water transfer system. C. paludica is a threatened endemic fish species from the Iberian Peninsula, and it exhibits sharply declining populations. Therefore, further investigation is needed to assess the genetic origin of the populations reported in this report and to monitor the population trends to determine the population status and the appropriate management plan in the Segura River Basin.
\end{abstract}

Key words: Cobitis paludica, Cobitidae, freshwater fish, Segura River, Mundo River.

\section{RESUMEN}

Primera cita de Cobitis paludica (de Buen, 1930) en la cuenca del río Segura (SE Península Ibérica)

El presente trabajo constituye la primera referencia al establecimiento de poblaciones viables de Cobitis paludica (de Buen, 1930) en la cuenca del río Segura. Se han detectado dos poblaciones separadas geográficamente: una localizada en la zona alta del río Segura y la desembocadura del río Zumeta, y otra en el río Mundo, entre los embalses de Talave y Camarillas. Su presencia puede ser debida a la introducción deliberada o accidental por parte de los pescadores, o a la translocación de ejemplares a través del trasvase Tajo-Segura. C. paludica es una especie amenazada endémica de la Península Ibérica cuyas poblaciones se encuentran actualmente en declive. En este sentido, es necesario realizar estudios genéticos que confirmen el origen de estas poblaciones y desarrollar protocolos de seguimiento para establecer su estado poblacional y el plan de gestión de esta especie en la cuenca del río Segura.

Palabras clave: Cobitis paludica, Cobitidae, peces de agua dulce, río Segura, río Mundo.

\section{INTRODUCTION}

The Southern Iberian spined-loach [Cobitis paludica (de Buen, 1930)] is an endemic loach that is widely distributed throughout numerous river basins in the central and southern regions of the Iberian Peninsula (Kottelat \& Freyhof, 2007). In Spain, the $C$. paludica distribution comprises the basins of the Ebro, Tajo, Guadiana, Guadalquivir, Guadalete, Guadalmedina, Barbate, Jara, Piedras, Vega, Peñíscola, Odiel, Júcar, Turia, Mijares, Bullent and Racons Rivers, Albufera de Valencia, and tributaries of the western margin of the Duero Basin (Doadrio, 2002). Recently, new populations of $C$. paludica were reported from the Limia and Serpis River Basins (Perea et al., 2011). 
The aim of the present study is to report the viable establishment of $C$. paludica in the Segura River Basin.

\section{MATERIALS AND METHODS}

A total of 65 specimens (Table 1) were collected in 7 out of a total of 35 sampling localities established in the rivers of the Segura Basin: Segura, Mundo, Taibilla, Zumeta and Tus. At each sampling locality (100-150 m long), electrofishing was performed from October 2008 to October 2011 with a standard equipment using a $2500 \mathrm{~W}$ generator (200-350 V, 2-3 A). The specimens were anaesthetised and preserved in $10 \%$ formalin solution. The total length ( $\mathrm{TL} \pm 1 \mathrm{~mm}$ ) was obtained for each individual at the laboratory. Some specimens are preserved in the ichthyological collections of the Zoology and Anthropology Department at the University of Murcia (CpSE04-1/CpSE04-25).

\section{RESULTS AND DISCUSSION}

We found two isolated populations that were geographically separated: one located in a $5 \mathrm{~km}$ long stretch in the upper part of Segura River and the mouth of its tributary, Zumeta River, and another in a long stretch of approximately 20 $\mathrm{km}$ in the Mundo River, between the Talave and Camarillas reservoirs (Table 1).
There are no historic records of $C$. paludica in the Segura River Basin (Mas, 1986; Torralva et al., 2005; Andreu-Soler et al., 2006). However, the observed abundance, size-groups and maximum lengths of this species in some of the sampling sites (Table 1) and the confirmed reproduction, as observed by the capture of juveniles and $0+$ individuals (less than $55 \mathrm{~mm}$ TL according to Oliva-Paterna et al., 2002), point to the viable establishment of the species in this river basin. The incipient populations of $C$. paludica demonstrated a low density compared to the coexisting translocated Iberian species, the Pyrenean gudgeon Gobio lozanoi (Doadrio \& Madeira, 2004) and the Iberian straight-mouth nase Pseudochondrostoma polylepis (Steindachner, 1864) (Martínez-Morales et al., 2010; Verdiell-Cubedo et al., 2011).

We hypothesised that the colonisation of the Segura River basin by $C$. paludica may be attributed to either one or a combination of the following causes: (1) its deliberate or accidental introduction by anglers because sport fishing is extremely popular in the sectors of the rivers where the species has been detected and because of the popular use of the species as bait (Doadrio, 2002) and (2) a consequence of fish translocation along the Tajo-Segura interbasin water transfer system, such as has been postulated for other introduced fish species in the Segura River Basin (García de Jalón et al., 1992; Torralva \& Oliva-Paterna, 1997; Andreu-Soler et al., 2004; Oliva-Paterna et al., 2005). Nevertheless, because $C$. paludica

Table 1. Sampling localities of the Segura River Basin where Cobitis paludica has been detected. The date of capture, UTM coordinates, number of captured individuals (n) and size range (total length $\pm 1 \mathrm{~mm}$ ) are indicated. Localidades de muestreo donde ha sido detectada la presencia de Cobitis paludica en la cuenca del río Segura. Se indican la fecha de captura, coordenadas UTM, número de individuos capturados ( $n$ ) y rango de tallas (longitud total $\pm 1 \mathrm{~mm}$ ).

\begin{tabular}{lllcrr}
\hline River & Locality & Date & UTM & $n$ & Size range (TL \pm 1 mm) \\
\hline Mundo & Tavizna & November 2010 & 30 S 0609845 4254770 & 4 & $46-92$ \\
Mundo & Mingogil & November 2010 & 30 S 0607953 4257440 & 16 & $30-90$ \\
Mundo & Isso & October 2011 & 30 S 0605999 4258359 & 8 & $43-85$ \\
Mundo & Talave & November 2008 & 30 S 0596224 4263787 & 3 & $62-80$ \\
Segura & Los Hornos & October 2009 & 30 S 0548673 4233250 & 8 & $42-81$ \\
Segura & Las Juntas & October 2008 & 30 S 0547822 4230254 & 14 & $47-90$ \\
Zumeta & Las Juntas & October 2008 & 30 S 0547820 4230129 & 12 & $31-84$ \\
\hline
\end{tabular}


is a threatened endemic species from the Iberian Peninsula and it presents sharply declining populations (Doadrio, 2002), further investigation is needed to assess the genetic origin of the populations reported here and to monitor the population trends to determine their status and the management plan in the Segura River Basin.

In the last decade, five non-native freshwater fishes have become established in the Segura River Basin (Torralva et al., 2005; Andreu-Soler et al., 2006), which, together with previously established non-native fish species, represent approximately $70 \%$ of the current freshwater fish fauna of this basin. The potential impact of the introduced species on the native fish fauna is difficult to ascertain because of the lack of specific studies concerning the interactions of the species or focusing on the biological traits of introduced fishes in the recipient novel aquatic habitats (Leunda, 2010). Taking into account the precarious conservation status of the Segura Basin freshwater fish fauna (Torralva et al., 2005), the translocation and establishment of a new species such as $C$. paludica, combined with the recent proliferation of several non-native invasive fish species, including bleak Alburnus alburnus (Linnaeus, 1758) and pumpkinseed Lepomis gibbosus (Linnaeus, 1758), suggest that monitoring studies are urgently needed to reinforce the scientific knowledge about the artificial pathways of fish introductions and the mechanisms by which the introduced fish may impact other species. Moreover, because anglers are known to be responsible for some recent invasions in the Iberian Peninsula (Leunda, 2010), increased public awareness and effective control of illegal introductions are needed.

\section{ACKNOWLEDGMENTS}

We thank all of those have helped us in the fieldwork: A. Andreu, R. Moreno, I. Martínez, D. Castejón and J. Caravaca. This study was financially supported by the projects "Efecto de la modificación antrópica del régimen hídrico sobre los peces epicontinentales nativos y exóticos de la cuenca del río Segura" (08728/PI/08, Fun- dación Séneca-Agencia de Ciencia y Tecnología de la Región de Murcia) and "Realización de las tareas de asesoramiento y supervisión de los trabajos de explotación de la red de control biológico en la cuenca del Segura y el establecimiento de las condiciones de referencia" (Confederación Hidrográfica del Segura).

\section{REFERENCES}

ANDREU-SOLER, A., F. J. OLIVA-PATERNA, D. VERDIELL-CUBEDO \& M. TORRALVA. 2004. Primeras citas de Alburnus alburnus (Linnaeus, 1758) y Tinca tinca (Linnaeus, 1758) (Actinopterygii, Cyprinidae) en la cuenca del río Segura (Murcia, sudeste de la Península Ibérica). Anales de Biología, 26: 222-224.

ANDREU-SOLER, A., F. J. OLIVA-PATERNA, D. VERDIELL-CUBEDO, A. EGEA-SERRANO, A. RUIZ-NAVARRO \& M. TORRALVA. 2006. Peces Continentales de la Región de Murcia (SE Península Ibérica): Inventario y Distribución. Zoologica Baetica, 17: 11-31.

DOADRIO, I. 2002. Atlas y Libro Rojo de los Peces Continentales de España. Dirección General de Conservación de la Naturaleza/Museo Nacional de Ciencias Naturales-CSIC. Madrid. 364 pp.

GARCÍA DE JALÓN, D., M. GONZÁLEZ DEL TÁNAGO \& C. CASADO. 1992. Ecology of regulated streams in Spain: An overview. Limnetica, 8: 161-166.

KOTTELAT, M. \& J. FREYHOF. 2007. Handbook of European freshwater fishes. Cornol. 646 pp.

LEUNDA, P. M. 2010. Impacts of non-native fishes on Iberian freshwater ichthyofauna: current knowledge and gaps. Aquatic Invasions, 5: 239-262.

MARTÍNEZ-MORALES, I., F. J. OLIVA-PATERNA, D. VERDIELL-CUBEDO \& M. TORRALVA. 2010. Inventario y estado de conservación de la fauna piscícola en la cuenca alta del río Segura (SE Península Ibérica). Anales de Biología, 32: 23-35.

MAS, J. 1986. La ictiofauna continental de la cuenca del río Segura. Evolución histórica y estado actual. Anales de Biología, 8: 3-17

OLIVA-PATERNA, F. J., A. ANDREU-SOLER, D. VERDIELL-CUBEDO \& M. TORRALVA. 2005. First occurrence of Lepomis gibbosus (L.,1758) in 
the Segura river basin (SE, Spain). Limnetica, 24: 199-202.

OLIVA-PATERNA, F. J., M. TORRALVA \& C. FERNÁNDEZ-DELGADO. 2002. Age, growth and reproduction of Cobitis paludica in a seasonal stream. Journal of Fish Biology, 60: 389-404.

PEREA, S., P. GARZÓN, J. L. GONZÁLEZ, V. C. ALMADA, A. PEREIRA \& I. DOADRIO. 2011. New distribution data on Spanish autochtonous species of freshwater fish. Graellsia, 67: 91-102.

TORRALVA, M. \& F. J. OLIVA-PATERNA. 1997. First record of Chondrostoma polylepis Steindachner, 1865 (Ostariophisi, Cyprinidae) in the basin of the river Segura, S.E. of Spain. Limnetica, 13: $1-3$.
TORRALVA, M., F. J. OLIVA-PATERNA, A. ANDREU-SOLER, D. VERDIELL-CUBEDO, P. MIÑANO \& A. EGEA-SERRANO. 2005. Atlas de Distribución de Peces Epicontinentales de la Región de Murcia. Dirección General del Medio Natural, Consejería de Industria y Medio Ambiente, CARM. 167 pp.

VERDIELL-CUBEDO, D., F. J. OLIVA-PATERNA, I. MARTÍNEZ-MORALES \& M. TORRALVA. 2011. Efectos de la modificación antrópica de los regímenes hidrológicos naturales sobre poblaciones de ciprínidos bentónicos de la Península Ibérica. In: Actas VII Congreso Ibérico sobre Gestión y Planificación del Agua. Fundación Nueva Cultura del Agua. Talavera de la Reina, Toledo. 